\title{
Peran Trehalose Metabolisme Sepanjang Masa Kehidupan Tanaman
}

\author{
Oleh: \\ Prapti Sedijani \\ Program Studi Pendidikan Biologi
}

\begin{abstract}
Trehalose/T6P has important role at entire plant stage of life starting from embryonic stage, vegetative growth, generative growth and senescence. The roles include cell devision, cell shape, plant architectecture, and plant responses to biotic and abiotic stress. Syncrunizing between energy demand and energy availability is the main mode of the roles through reprogramming of gene expression responsible for anabolism and/or catabolism processes depending on given situation including biotic and abiotic stress. Moreover, proteins of trehalose metabolism are suggested to affect enzyme activity of target proteins. SnRK1 and bZIP11 involve in all those modes. Understanding crusial roles of trehalose metabolism in plant therefore is necessary in order to get benefit from this pathway for agricultural issue.
\end{abstract}

\begin{abstract}
Abstrak
Trehalose/T6P berperan penting bagi tahapan kehidupan tanaman dari tahap embryo, pertumbuahn vegetatif, pertumbuhan generatif, hingga sanesensi. Peran molekul tersebut berpengaruh pada pembelahan sel, bentuk sel, arsitektur tanaman dan respon tumbuhan terhadap stres biotik dan abiotik. Pengintegrasian antara kebutuhan dan ketersediaan energi merupakan modus utama dalam peran tersebut melalui pemrograman ekspresi gen yang bertanggung jawab terhadap proses anabolisme dan atau katabolisme sesuai dengan situasi tertentu termasuk dalam kondisi stres biotic dan abiotik. Selain itu, protein-protein dalam lintasan metabolisme trehalose ini juga diduga mempengaruhi aktivitas enzimenzim target. Peran krusial metabolisme trehalose, manusia dapat memanfaatkan lintasan ini untuk kepentingan pertanian.
\end{abstract}

\section{PENDAHULUAN}

7 Uumbuhan sebagai mahluk sesil tidak bias memilih tempat tumbuhnya, oleh karena itu, tanaman tidak harus menghadapi tantangan biotic maupun abiotik dari lingkungannya. Pemahaman mengenai bagaimana tumbuhan menghadapi, beradaptasi dan bertahan hidup adalh menarik untuk dipelajari dan agar dapat dimanfaatkan untuk kepentingan manusia dalam dunia pertanian. Salah satu dari mekanisme tersebut melibatkan lintasan metabolism trehalose.
Trehalose adalah gula sederhana disakarida terdiri atas dua molekul glukosa yang dihgubungolvean satu sama lain dengan ikatan glikosida $\alpha-\alpha$ 1-1. Gula ini termasuk dalam gula non reduksi, mempunyai tingkat kemanisan sekitar $45 \%$ dibanding sukrosa (Higashiyama, 2002). Bersifat amourphous (tak berbentuk) pada kondisi 100\% tanpa air (Hagen et al 1995). Gula ini banyak ditemukan pada organism tingkat rendah bakteri dan jamur, tanaman tingkat rendah serta pada tanaman yang teradaptasi dengan kehidupan yang keras 
seperti iklim gurun (Zentella et al 1999). Berikut review yang menjelaskan peran trehalose dalam kehidupan tumbuhan, termasuk bertahan menghadapi stress biotic dan abiotik.

\section{PEMBAHASAN}

\section{Karakter trehalose}

Trehalose, sebagai gula non reduksi, tidak mudah didegradasi oleh faktor luar kecuali didegradasi secara enzimatis. Konskwensinyanya gula ini tidak mudah mengalami perubahan struktur fisika maupun kimianya dalam berbagai kondisis lingkungan dalam rentang yang luas, misalnya terhadap perubahan suhu, $\mathrm{pH}$ dan status air (Higashiyama, 2002). Yang unik dari trehalose bukan saja sifat alamiah molekulnya sendiri stabil, tapi juga bersifat menyetabilkan molekul-molekul yang ada disekitarnya, termasuk molekul biologi (Higashiyama, 200) misalnya terhadap suhu (Doehlemann etal, 2006; Patist et al, 2005), garam tiggi (Chang et al 2014) dan oxidative stress (Echigo et al 2012). Untuk itu trehalose juga dijuluki sebagai biological stabilizing agent atau stress protecting agent (Shinohara et al, 2002), menjelaskan bahwa, trehalose adalah gula paling efektif dalam menstabilkan materi biologi (Crowe 2008; Magazù et al., 2012). Test juga dilakukan terhadap 6 macam disaccharida yang dicoba, trehalose paling bagus dalam melindungi membrane. Pernyataan ini didasarkan atas percobaan dengan menambahkan $1 \mathrm{ml} \mathrm{5 \%}$ trehalose ke dalam 100 g lipid, direbus selama 24 jam, kemudian volatile pecahan lemak yang terbentuk dianalisis. Dari larutan lemak trehalose yang paling sedikit ditemukan lemak volatile. Trehalose juga mampu mempertahankan sifat alamiah dari materi non biologi, sehingga gula ini sering digunakan untuk memperpanjang masa kadaluwarsa makanan (Higashiyama, 2002).
Kemampuan trehalose dalam mempertahankan sifat alami materi yang ada disekitarnya tidak terlepas dari karakter trehalose. Dilaporkan ada 3 teori untuk fungsinya sebagai stress protecting agent. Trehalose berperan sebagai water replacement, water entrapmen dan glass forming agent. Sebagai water replacement, trehalose mempunyai kemampuan untuk mebentuk ikatan hydrogen dengan molekul yang ada disekitarnya (Lefort et al 2007). Dengan lipid misalnya, setiap molekul trehalose dapat membentuk hingga delapan ikatan hydrogen dengan minimal 3 molekul lipid (Pereira et al 2004, Patist et al 2005). Sifat ini berkontribusi besar terhadap integritas membran saat mengalami stres. Stres air misalnya, membran sel akan mengalami perubahan sesuai dengan komposisi unsur penyusun membran. Sebagai bilayer, komposisi anatara membrane luar dan membrane dalam tidak sama, dan kompisis di setiap bagian setiap dari lapisan membrane juga tidak sama. Masing-masing unsur penyusun mempunyai karakter yang berbeda dan merespon berbeda dengan perubahan lingkungan yang sama. Pada saat membran mengalami kekeringan, misalnya, setiap unsur dari membrane tersebut mengalami perubahan bentuk, struktur, derajad kekakuan, sifat kimia dan fisikanya sesuai dengan karakternya masing-masing yang mengakibatkan perubahan fase membran, dari fase fluid (fase fisiologis) menjadi fase gel yang kaku dan tidak lagi mendukung fungsi fisiologis membran. Bahkan bisa terjadi pemisahan protein integral mebran, robeknya membran, dan fusi antar lapisan membran, dan atau membrane antar sel (Lenne et al 2007). Dengan adanya trehalose yang mampu memberikan ikatan hydrogen yang sama seperti yang diberikan oleh air, sehingga integritas membran lebih terjaga setidaknya kerusakan membran dapat dikurangi. Contoh peran trehalose 
dalam penstabilan materi biologi sangat banyak untuk didaftar, salah satunya asam fosfatidat derivate dari lipid yang terjaga oleh trehalose dari stres kekeringan, garam dan beku (Testerink and Munnik, 2011).

Peran trehalose sebagai water entrapment, trehalose berperan penjerap air (adsorbsi). Dengan kemampuannya membentuk ikatan hydogren dengan meteri biologi sekaligus membentuk ikatan hydrogen dengan air, trehalose membuat air lebih tersedia bagi proses-proses fisiologi materi biologi. Dalam keadaan beku trehalose membentuk matrik gelas, membuat materi biologi mendapatkan supot mekanik sebagaimana berada didalam matrik gelas menyebabkan materi biologi terjaga struktur alamiahnya saat stress beku oleh suhu dingin. Terjaganya struktur mekanik ini menjaga materi biologi terhindar dari kerusakan dan tidak kehilangan fungsi fisiologisnya. Selain itu, trehalose mengurangi kerusakan akibat suhu dingin ini dengan mengurangi derajad kebekuan air sehingga air yang tidak beku lebih tersedia. Peran ini sesuai dengan karakter trehalose sebagai solute pemecah koordinasi struktur tetrahedral dari iaktan hydrogen pada air. Air dalam suhu ruang berbentuk cair karena ikatan hydrogen antar molekul air selalu dinamis antara sambung dan putus. Es terbentuk ketika ikatan hydrogen tetrahedral antar molekul air berlangsung lama dalam keadaan tidak putus. Dengan adanya gula ikatan hydrogen tetrahedral pada air menjadi terganggu dan derajad kebekuan berkurang. Diantara gula yang sering digunakan untuk mengurangi terbentuknya es, trehalose paling tinggi mengurangi terbentuknya es. Sifat ini juga sering diaplikasikan dalam laboratorium untuk menjaga keawetan materi biologi, sebagai contoh, Lee et al., 2013 melaporkan bahwa penggunaan 50 $\mathrm{mM}$ trehalose dalam cryopreservasi sperma menghasilkan viabilitas sel lebih tinggi dibanding menggunakan DSMO. Sedang preservasi dengan $200 \mathrm{mM}$ trehalose menghasilkan proliferasi sel yang lebih tinggi dan sel apoptosis lebih rendah dibanding preservasi menggunakan DSMO $200 \mathrm{mM}$.

Sifat-sifat trehalose disebutkan didepan lebih relevan dengan peran trehalose sebagai stress protektant melalui osmotic adjustment yang mana konsentrasi tinggi diperlukan untuk mendukung fungsi tersebut. Biasanya peran ini didemonstarsikan pada organism tingkat rendah dimana trehalose ditemukan dalam jumlah yang tinggi seperti pada archea, bakteri, jamur, avertebrata dan tumbuhan teradaptasikan terhadap iklim gurun.

Trehalose juga membantu mengurangi kerusakan dengan berfungsi sebagai chaperon yang membantu mengurangi kerusakan protein stelah mengalami stres. Protein yang mengalami mutasi bisa terbantu pelipatan mendekati normal sehingga mengurangi tingkat hilangnya aktivitas. Trehalose juga terlibat dalam meningkatkan ketahanan terhadap biotik stres. Pada tanaman tingkat tinggi trehalose disintesis dalam jumlah yang sangat sedikit dan dikontrol dengan sangat ketat. Namun demikian, trangenik yang mengekspresikan gen dalam lintasan metabolisme trehalose mempunyai ketahanan terhadap beberapa macam stress (Garg et al, 2002, Jang et al 2003, Debast 2011). Peningkatan ini tidak diikuti oleh peningkatan trehalose yang signifikan. Hal ini mengundang pertanyaan dengan cara bagaimana gen dalam lintasan biosintesis trehalose membuat tanaman menjadi lebih tahan terhadap beberapa macam stress. Mekanisme ini bukan melalui osmotik adjustment seperti pada organisme tingkat rendah atau tanaman gurun, tapi trehalose/T6P berperan sebagai signaling molekul. Paragraf-paragraf dibawah dikumpulkan dari publikasi tentang aspek-aspek yang dipengaruhi oleh 
gen-gen dalam lintasan metabolisme trehalose dengan pertumbuhan dan perkembangan serta efek trehalose metabolisme dalam meningkatkan ketahanan tanaman terhadap stres.

\section{Metabolit trehalose, T6P sebagai neraca ketersediaan dan pemakaian karbon.}

T6P dilaporkan mempunyai peran sangat penting bagi kehidupan tumbuhan terkait dengan metabolism dan perkembangan (Ponnu, etal 2011), sejak pembelahan sel (Smekeens et al 2010; Tsai and Gozassarini, 2013) hingga sanessensi (Wingler, et. Al., 2012). T6P, substrat trehalose mempunyai peran sebagai integrator antara ketersediaan sumber dan penggunaan karbon. Kandungan T6P pada tanaman meningkat seiring dengan meningkatnya kandungan sucrose (Lunn et al., 2006; Martinez-Barajas et al., 2011). Tingginya T6P menginduksi gen-gen terkait dengan pertumbuhan, memacu ekspresi gen anabolisme dan menekan ekspresi gen katabolisme. Tingginya T6P juga menghambat ekspresi gen sucrose nonfermenting related-kinase 1 (SnRK1) yang merupakan signal untuk stres dan terinduksi oleh stres terutama stres energi (Baena González and Sheen, 2008). Akumulasi AMP sebagai akibat dari terpakainya ATP menginduksi ekspresi SnRK1 selanjutnya SnRK1 menekan ekspresi gen terkait anabolisme dan pertumbuhan (Crozet, et. Al., 2014). Meningkatnya eksprei SnRK1 juga mengakibatkan ekspresi gen yang diprogram untuk katabolisme terutama katabolisme protein, antara lain asparagin synthase (Baena Gonzales, et. Al., 2007). SnRK1 diperlukan dalam ekspresi gen $\alpha$ amylase pada embryo gandum dan padi saat kekurangan sucrose (Laurie, et. al., 2003; Lu. Et. al., 2007) menunjukkan bahwa SnRK1 berperan dalam pemecahan pati saat kelaparan. Overexpresi gene KIN10 (penyandi katalitic unit dari SnRK1) menyebabkan meningkatnya ekspresi 1000 putative gen target KIN10 yang terlibat dalam katabolisme dan menurunnya ekspresi gen yang terlibat dalam anabolisme (BaenaGonzález and Sheen, 2008).

Tingginya T6P juga meningkatkan ekspresi gen yang terkait dengan prosesproses yang memerlukan NADPH (Kolbe et al., 2005; Michalska et al., 2009), meskipun belum ada bukti yang jelas bahwa NADPH berinteraksi dengan protein TPS1; atau TPS1 mempengaruhi kinerja enzim glukosa 6P dehydrogenase, G6PDH (Schluepmann, et. al. 2012). Hal ini menegaskan bahwa T6P memacu proses anabolisme. Bila T6P terlalu banyak mengakibatnya berkurangnya stok Glukosa 6 phosphate (G6P), substrat untuk pembentukan NADPH melalui jalur oksidasi pentose pospat dan substrat energi melalui jalur glikolisis yang selanjutnya menghasilkan ATP. Dengan berkurangnya $\mathrm{NADPH}$ sebagai energi dalam proses anabolisme dan pertumbuhan, proses tersebut akan melambat. Delatte, et. al. (2011) memaparkan bahwa tingginya T6P tanpa adanya tambahan sumber karbon akan menghabiskan sumber karbon karena penggunaan yang berlebihan, dan karena terhambatnya proses ekspresi gen yang bertanggung jawab untuk proses katabolisme. Sebaliknya bila T6P terlalu sedikit, ekspresinya SnRK1 meningkat, ekspresi gen anabolisme dihambat oleh SnRK1, sehingga tidak ada pertumbuhan, untuk Arabidopsis terhenti pada tahap terpedo (Schluepmann, et. al., 2003). Dengan demikian, T6P ikut berperan dalam neraca penyelaras antara karbon yang tersedia dan pengguanaanya termasuk termasuk proses-proses yang mendukung pertumbuhan. Proses-proses yang terpengaruh oleh neraca karbon ini antara 
lain dipaparkan dalam paragraf berikut.

\section{Peran trehalose metabolisme sepanjang kehidupan tanaman}

T6P ikut berperan dalam jaringan meristematis: pembelahan sel, pembentukan dinding sel, dan penentuan arsitektur tanaman.

Pada Saccharomyces cerevisiae, trehalose bersinergi dengan glycogen mempengaruhi siklus sel. Mutant sel yang kehilangan kemampuan mensintesis trehalose membelah dengan kecepatan sama dengan tipe liarnya jika ditumbuhkan pada kondisi sumber energi yang terbatas, namun jika ditumbuhkan dalam kondisi normal dengan sumber energi yang memadai, mutant sel membelah lebih lambat dibanding tipe liar. Hal ini menunjukkan bahwa trehalose diperlukan untuk proses normal pembelahan sel. Selain itu sel ragi tipe liar bertahan lebih lama dalam medium dengan sumber energi terbatas (Silije et al 1999).

Pada tanaman, T6P dilaporkan berinteraksi dengan protein yang mengatur pembelahan sel, CDKA1 dan Kinesin KCA1 (Smeekens 2010) yang mengindikasikan kemungkinan T6P ikut berperan dalam pembelahan sel, dan diduga melalui T6P/SnRK1 dalam mensinkrunkan antara energi tersedia dengan penggunaannya seperti siklus sel. Tsai and Gazarrini (2013) mengemukakan bahwa T6P secara tidak langsung mempengaruhi pembelahan meristematik sel yang pada akhirnya memacu fase $\mathrm{G} 2$ ke fase $M$ dengan berikatan dengan regulator pembelahan sel. Selain itu, UDPdehydrogenase yang terlibat dalam biosintesis dinding sel sangat terinduksi oleh meningkatnya T6P (Klinghammer and Tenhaken, 2007). Namun demikain mekanisme persisnya bagaimana T6P berperan dalam semua itu masih dalam penyelidikan (Wang and Ruan, 2013).

T6P berperan dalam determinasi sel meristem. Tingginya T6P merupakan signal adanya sumber energi, sehingga sel meristem pada malai bunga terinduksi untuk membuat cabang baru, sehingga terbentuk malai dengan jumlah cabang yang banyak (Satoh-Nagasawa et al., 2006). Apikal dominasi tereduksi oleh overekspresi gen OtsA pada Adabidopsis, dan fenotipe sebaliknya pada transgenik dengan overekspresi gen OtsB (Schluepmann, et. al., 2003; van Dijken, et. al., 2004). Selain itu TPS6 salah satu family dari gen trehalose synthase berperan dalam morfogenesis seluler (Chary, et. al., 2008). Bukti dari penyataan tersebut bahwa gen Trehalose phosphate phosphatase 6 (TPS6) dapat mengkomplementasi mutan Arabidopsis pada gen Cell shape phenotype-1 (csp-1) yang mengalami perubahan bentuk dan ukuran sel serta percabangan trikoma kembali menjadi normal.

Trehalose terlibat dalam determinasi meristematis sel dengan mengintegrasikan hormon dan sumber karbon. Ramosa 3 menyandikan Trehalose phosphate phosphatase (TPP) pada jagung (SatohNagasawa et al., 2006). Mutant Ramosa 3, ra3 meningkatkan percabanagan pada malai bunga jantan dan bunga betina (Satoh-Nagasawa et al., 2006). Mutant tersebut mengalami perubahan tingkat ekspresi gen faktor transkripsi yang terlibat dalam pertumbuhan dan perkembangan dan ekspresi gen yang terlibat dalam sensing dan signaling hormone (Eveland et al 2010). $R A 3$ mempunyai fungsi yang sama dengan RA1 dan RA2, dan berada disekitar area meristematis. Studi spatiotemporal dan keberadaan RA1 dalam genom menunjukkan bahwa RA1 berperan dalam determinasi meristem melalui sintesis dan signaling gibberelin dan auxin, serta dengan berinteraksi dengan protein yang bertanggung jawab terhadap pemeliharaan sel meristem, KNOTTED1. RAl juga 
berinteraksi dengan protein yang menetukan identitas meristem bunga, $L E A F Y$ (Eveland 2014). Dengan demikian, T6P berperan dalam determinasi sel meristem melalui signaling hormone dan ketersediaan sumber energi.

T6P ikut berperan dalam perkembangan embryo dan fase vegetative

Terdapat dua fase transisi pada tanaman, yakni transisi dari fase embryo ke vase vegetative (germinasi) dan dari fase vegetative ke fase reproduktif (pembungaan). Dalam fase transisi ini terjadi perubahan ekspresi gen secara masif dan membutuhkan banyak energi. Dalam proses tersebut juga terjadi remobilisasi serta ketepatan alokasi nutrisi termasuk karbohidrat (Tsai and Gazzarini, 2014). Selama perkembangan embryo, setelah pola sel terbentuk diikuti dengan pematangan embryo yang dimulai dari tahap torpedo. Pada tahap pematangan ini pembelahan sel istirahat, dan beralih kepada pembesaran sel dan penyimpanan cadangan makanan serta penyiapan dormansi biji dan ketahanan terhadap kurangnya air. Pematangan biji ini diinduksi oleh ABA dan faktor-faktor transkripsi. Konsentrasi ABA paling tinggi dipertengahan perkembangan embryo untuk memacu kematangan embryo dan di akhir tahap embryo untuk mendorong penyimpimpanan cadangan makanan dan menyiapkan dormansi biji. Pada tahap torpedo, dimana pematangan embryo dimulai, ekspresi gen TPS1 meningkat (Gutierrez et al., 2007). Mutant biji Arabidopsis tps 1 pada gen TPS mengalami embyo letal (Eastmond, et. al., 2002). Kondisi ini dapat diperbaiki dengan komplementasi TPS dari E.coli yang mengindikasikan bahwa T6P sangat krusial bagi perkembangan embryo (Schluepmann, et. al., 2004). Studi anatomi, fisiologi dan ekspresi gen yang dilakukan oleh Gomes, et. al., (2006) menunjukkan bahwa TPS1 diperlukan dalam proses penyimpanan cadangan makanan. Sintesis pati misalnya, T6P mengaktifkan enzim adenosine-5' diphosphoglucose pyrophosphorylase (AGPase) melalui aktivasi post translasi untuk menintesis pati (Kolbe et al 2005).

T6P juga diperlukan pada tahap pertumbuhan vegetative tanaman. Eastmond et al., (2002) membuat tanaman transgenik mutan tps 1 yang dikomplementasikan dengan gen TPS dengan promoter yang dapat diinduksi oleh dexamethazone. Pada saat di induksi dengan hormon tersebut, tanaman tumbuh normal, namun pertumbuhan terganggu saat dexamethazone tidak tersedia. Hal ini menunjukkan bahwa ekspresi gen TPSI sangat penting untuk pertumbuhan vegetatif tanaman. Tanaman yang dimutasikan agar mempunyai alel lemah mengalami pertumbuhan yang terhambat dibanding dengan tipe liarnya (Gómez et al., 2010). Demikian juga dengan tanaman transgenik yang mengekspresikan gen penyandi enzim pendegradasi T6P, Trehalose phosphate phosphatase (TPP) dan Trehalose phosphate hydrolase (TPH), mengalami pertumbuhan yang lambat (Schluepmann, et. al., 2003). Dengan demikian jelas bahwa T6P tidak bisa diabaikan perannya dalam pertumbuhan tanaman fase embryo maupun fase vegetatif.

T6P ikut berperan dalam pembungaan, alokasi sumber energi and arsitektur tanaman

Expresi gen OtsB dari E.coli yang mengkode enzim pemecah T6P mengakibatkan penundaan waktu pembungaan, sebaliknya ekspresi OtsA menyebabkan pembungaan lebih awal (Schluepmann et al 2003; Wahl et al, 2013). FLOWERING LOCUS T (FT) disintesis di daun dan berpindah ke Shoot 
apical meristem (SAM) untuk memicu pembungaan yang didinduksi oleh fotoperiod. Tingkat ekspresi FT yang rendah ditemukan pada tanaman transgenik yang didesain untuk rendah T6P, bahkan hampir tidak ada ekspresi pada tanaman mutan tps 1; selanjutnya mutant tps1 kembali menjadi normal jika ditransformasi lagi dengan TPS1 (Wahl, 2013). Sejalan dengan ini, waktu pembungaan dihambat olek SnRK1, dimana SnRK1 dihambat oleh T6P. FLOWERING LOCUS $C$ (FLC) adalah repressor pembungaan. Absisic Acid Insensitif mutant 5 ( $A B I 5)$ menghambat pembungaan dengan menginduksi ekspresi gen FLC. ABI5 secara invitro diposporilasi oleh SnRK1. Sedang SnRK1 dihambat oleh T6P. Dengan demikian, ABI5 mengintegrasikan antara hormone dan signal sumber energi untuk mengatur pembungaan.

Kandungan T6P pada Arabidopsis berkorelsi dengan konsentrasi sukrosa pada saat perkembangan biji. Kandungan T6P 100x melebihi jumlah diluar pengisian biji pada gandum (Martínez-Barajas, et. al., 2011). Demikian juga dengan gen TPS1 secara konsisten diekspresikan dalam jumlah yang tinggi sepanjang waktu pengisian biji. Namun 10 hari setrelah antesis, T6P hanya ditemukan dalam jumlah yang sangat kecil di kotiledon (Zhang, et. Al., 2011). Masih berkaitan alokasi karbon, SnRK1 dihambat oleh T6P pada umbi kentang yang sedang tumbuh (Debast et al., 2011) dan pada masa penyimpanan gula tanaman tebu $(\mathrm{Wu}$ and Birch, 2010), menunjukkan bahwa T6P terlibat dalam alokasi sumber karbon saat penyimpanan cadangan makanan.

Sebagaimana disebut diatas bahwa T6P bekerja dalam jaringan meristematis, dan menentukan arsitektur dari jaringan/organ, peran ini juga terlihat pada jaringan meristematis bunga. Satoh-
Nagasawa et al (2006) melaporkan bahwa mutasi pada gen yang mempunyai aktifitas TPP, ramose3 (RA3) menunjukkan percabgangan yang tidak normal pada bunga jagung baik pada bunga jantan maupun pada bunga betina. Sejalan yang telah dikemukakan didepan, TPS6 yang diketahui tidak berfungsi aktif (Ramon, et. al., 2009), terlibat dalam determinasi sel meristem (Chary, et. al., 2008), mengindikasikan bahwa gen-gen dalam linatasan metabolisme trehalose berevolusi untuk memenuhi fungsi sebagai molekul signal dari pada sebagai enzim yang aktif dalam katailisis reaksi (O'Hara, et. al., 2013). Selanjutnya Autornya mengemukakan bahwa protein-protein tersebut berfungsi sebagai sensor terhadap konsentrasi T6P dalam sel yang sekaligus menunjukkan ketersediaan sumber energy dalam sel. Interaksi antara protein-protein tersebut dengan TPS1 yang fungsional didemonstrasikan terjadi pada padi (Zang, et al., 2011). Selanjutnya protein-protein tersebut diperkirakan terlibat dalam regulasi dan pemrograman transkripsi dan translasi (Satoh-Nagasawa et al 2006).

\section{T6P berperan dalam sel sanesen}

T6P diperlukan untuk terjadinya sanesensi, yakni dengan terekspresinya gen-gen untuk anabolisme, termasuk untuk protein sintesis. T6P meningkat pada daun yang telah tua, hal ini diduga bahwa keberadaan T6P pada daun tua tersebut adalah untuk remobilisasi nitrogen dari daun tua ke jaringan yang sedang tumbuh (Wingler et al, 2012). Transgenik Arabidopsis yang mengekspresikan gen Ots $A$ mengalami sanesensi lebih cepat dari pada tipe liarnya. Sedang transgenik yang mengekspresikan gen OtsB lebih lambat untuk terjadinya sanesensi. Hal ini sejalan dengan T6P meningkat pada daun menjelang sanesence (Wingler et al, 2012). Marker gen untuk sanesensi juga 
meningkat pada transgenik OtsA, dan menurun pada transgenic OtsB. Demikian juga untuk kandungan klorofil, Transgenik OtsB lebih pucat dibanding transgenik OtsA, tapi lebih lama hijau dibanding OtsA. Disamping itu, penambahan gula tanpa penambahan sumber nitrogen mempercepat sanesensi. Padahal transgenic $O t s B$ megakumualsi gula lebih banyak dibanding dibanding tipe liar dan OtsA, namun $O t s B$ mengalami sanesensi lebih lambat, dengan demikian, gula saja belum cukup untuk sanesensi, T6P diperlukan.

Peran trehalose menghadapi stress tanaman biotik dan abiotik stress.

Tanaman yang mengakumulasi trehalose dalam jumlah tinggi anatara lain lumut, paku-pakuan dan tanaman yang terdaptasikan dengan iklim gurun antara lain Selaginella lepidophylla, myrothamnus flabiofolia (Elbein et al, 2003). Pada tanaman tingkat tinggi seperti

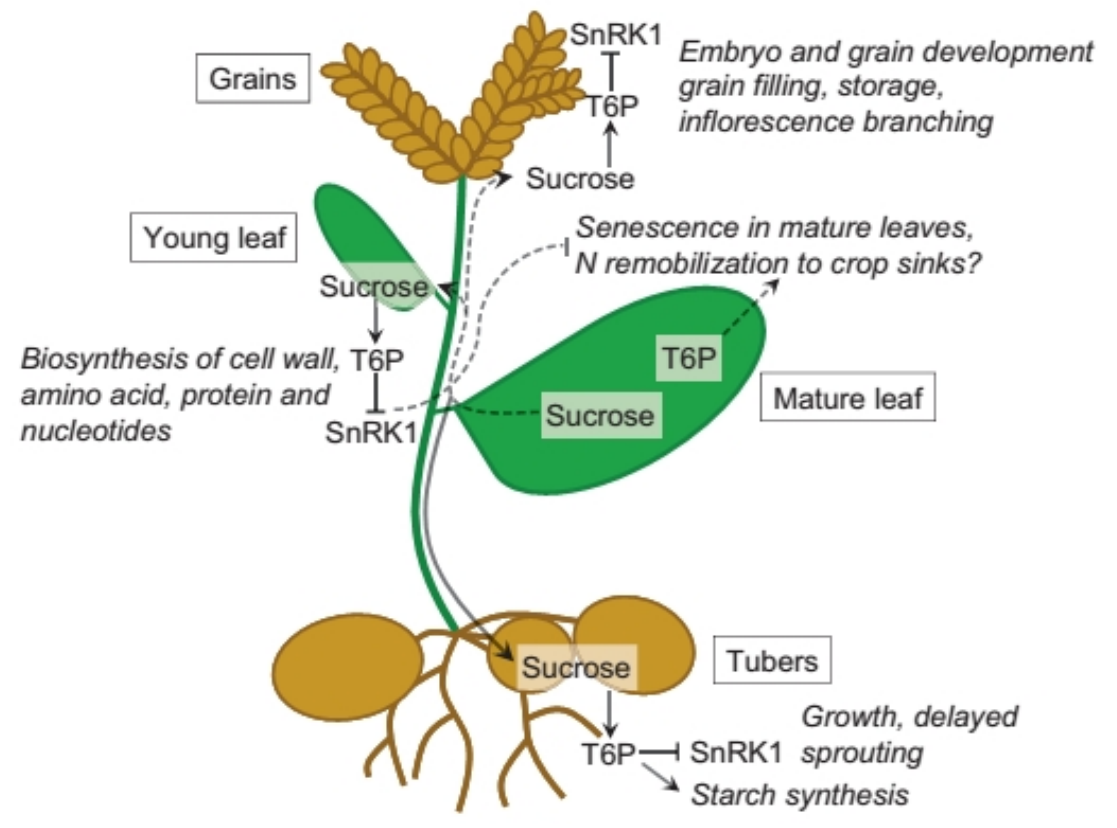

Gambar 1. Ilustrasi peran T6P pada tanaman pangan ditunjukkan pada tanaman hipotetis (diambil dari O'Hara et al., 2013). Konsentrasi T6P meningkat dengan meningkatnya sukrosa, hampir semua proses yang dipengaruhi oleh T6P (yang dicetak miring) terjadi melalui penghambatan T6P terhadap SnRK1, lebih lengkap dijelaskan dalam teks.

Tanaman budidaya, trehalose disintesis dalam jumlah yang hampir tidak terdeteksi (Schluepmann, et. al., 2003), untuk itu para terdahulu mencoba mengekspreikan gen penyandi enzim biosintesis trehalose untuk meningkatkan ketahanan tanaman terhadap stress. Terbukti bahwa tanaman transgenik yang dihgasilkan lebih tanahan terhadap beberapa macam stress. Sebagian dari daftar yang panjang tanaman transgenik membawa gen dalam family dan terbukti meningkatkan ketahanan terhadap stres antara lain stress terhadap suhu dan garam pada padi transgenik (Garg et al, 2002, Jang et al, 2003; Lee et al 2014); pada tembakau (Karim et al 2007); Arabidopsis (Miranda et al 2007) dan pada chatarantus roseus (Chang et al, 2014), terhdap terhadap suhu dingin, misalnya pada nggur (Fernandez et al 2012) dan masih banyak lagi yang tidak bisa di daftar disini. Trehalose juga berperan dalam merespon stres terhadap biotik stres, misalnya green apid pada tanaman tomat (Singh et al 2011) 
dan pada tanaman gandum dari powdery mildew (Reignault, et al., 2000; Tayeh, et al., 2014).

Kandungan trehalose pada tanaman transgenik tersebut tidak mengakumulasi trehalose dalam jumlah yang significant. Hal ini menunjukkan bahwa meningkatnya ketahanan tanaman trangenik terhadap beberapa stress tersebut bukan karena peran trehalose sebagai osmotik adjustment (Avonce et al., 2006; Fernandez et al., 2010). Didepan sudah disiskusikan bahwa T6P/SnRK memegang peran central dalam integrasi antara sumber karbon tersedia dengan penggunaannya yang di disinkrunkan dengan pertumbuhan dan perkembangan tanaman melalui reprogramming ekspresi gen-gen target, dan dan disesuaikan dengan kebutuhan spesifik saat tertentu. T6P/SnRK1 signaling ini juga mengintegrasikan antara sumber karbon dengan respon terhadap lingkungan, baik biotik maupun abiotik. Pada gandum, misalnya, (Tayeh, et.al., 2014) melaporkan bahwa aplikasi trehalose meningkatkan ekspresi gen penyandi pathogen related protein; chitinase (chi1, chi2, dan precursor ch4); oxalate oxidase (OXO) dan lipoxygenase (lox). Sedang aplikasi terhadap tanaman gandum yang terinfeksi oleh Powdery mildew, Autor menyebutkan bahwa, gen yang secara spesifik berubah tingkat ekspresinya akibat aplikasi trehalose adalah precursor Chi4 dan lox, dibarengi dengan meningkatnya aktivitas LOX dan berhentinya pertumbuhan jamur. Hal ini menunjukan bahwa trehalose berperan dalam pertahanan tanaman (Tayeh, et. al., 2014). Penyemprotan trehalose $0.1-15 \mathrm{gr} / \mathrm{L}$ trehalose sebelum diinokulasi dengan powdery mildew menurunkan $60 \%$ infeksi jamur tersebut (Muchembled, et. al., 2006). Masih pada tanaman gandum, penyemprotein dengan $15 \%$ trehalose mengurangi terajadinya infeksi sebanyak 50 dan 95\% masing- masing bila 1 kali atau 3 kali pnyemprotan. Ketahanan ini terjadi karena trehalose meningkatkan aktivitas polyamine lyase (PAL) dan peroxidase (PO) serta meningkatkan penebalan dinding sel (Reignault, et al., 2000).

\section{SIMPULAN}

Trehalose berperan sepanjang masa kehidupan tanaman sejak pembentukan embryo hingga sanesensi baik untuk program pertumbuhan dan perkembangan tanaman maupun untuk merespon dan bertahan terhadap stress dari lingkungan dengan cara mengintegrasikan ketersediaan sumber energy dan penggunaanya serta melalui pemrograman ekspresi gen-gen target atau meregulasi aktivitas protein target. Pemahaman yang mendalam tentang metabolisme trehalose perlu dikuasai untuk dapat memanfaatkan lintasan ini untuk keperluan manusia.

\section{DFTAR PUSTAKA}

Avonce, N., Mendoza-Vargas, A., Morett, E., and Iturriaga, G.(2006). Insights on the evolution of trehalose biosynthesis. BMC Evol. Biol 6, 109

Baena-González, E., and Sheen, J.(2008). Convergent energy and stress signaling. Trends Plant Sci. 13, 474482.

Baena-González, E., Rolland, F., Thevelein, J.M., and Sheen, J. (2007). A central integrator of transcription networks in plant stress and energy signaling. Nature. 448, 938-942.

Benaroudj N, Lee DH, Goldberg AL. Trehalose accumulation during cellular stress protects cells and cellular proteins from damage by oxygen radicals. J Biol Chem. 2001;276:24261-24267.

Chang B, Yang L, Cong W, Zu Y, Tang Z (2014). The improved resistance to high salinity induced by trehalose is 
associated with ionic regulation and osmotic adjustment in Catharanthus roseus. Plant Physiology and Biochemistry: PPB / Societe Francaise de Physiologie Vegetale, 77:140-148. Chary SN, Hicks, GR, Choi YG, Carter D and Raikhel NV (2008). Trehalose-6Phosphate Synthase/Phosphatase Regulates Cell Shape and Plant Architecture in Arabidopsis. Plant Physiol. 2008 Jan; 146(1): 97-107.

Crowe, J.H (2008). Trehalose and anhydrobiosis: The early work of J. S. Clegg. J Exp Biol. 2008:2899-2900.

Crozet P, Margalha L, Confraria A, Rodrigues A, Martinho C, Adamo M, Elias CA and Baena-González (2014). Mechanisms of regulation of SNF1/AMPK/SnRK1 protein kinases. Front. Plant Sci., 20 May 2014

Debast, S., nunes-nesi, A., Hajirezaei, M.R., Hofmann, J., Sonnewald, u., Fernie, A.R., and Börnke, F. (2011). Altering trehalose-6-phosphate content in transgenic potato tubers affects tuber growth and alters responsiveness to hormones during sprouting. Plant Physiol. 156, 17541771.

Delatte, T.L., Sedijani, P., Kondou, Y., Matsui, M., de Jong, G.J., Somsen, G.W., Wiese-Klinkenberg, A., Primavesi, L.F., Paul, M.J., and Schluepmann, H.(2011). Growth arrest by trehalose-6-phosphate: an astonishing case of primary metabolite control over growth by way of the SnRK1 signaling pathway. Plant Physiol. 157, 160-174.

Doehlemann G, Berndt $P$ and Hahn $M$ (2006). Trehalose metabolism is important for heat stress tolerance and spore germination of Botrytis cinerea. Microbiology September 2006 vol. 152 no. 9 2625-2634

Eastmond, P.J., van Dijken, A.J., Spielman,
M., Kerr, A., Tissier, A.F., Dickinson, H.G., Jones, J.D., Smeekens, S.C., and Graham, I.A.(2002). Trehalose-6phosphate synthase 1 , which catalyses the first step in trehalose synthesis, is essential for Arabidopsis embryo maturation. Plant J. 29, 225-235.

Echigo R, Shimohata N, Karatsu K, Yano $\underline{F}$, Kayasuga-Kariya Y, Fujisawa A, Ohto T, Kita Y, Nakamura M, Suzuki S, Mochizuki M, Shimizu T, Chung UI, Sasaki N (2012).Trehalose treatment suppresses inflammation, oxidative stress, and vasospasm induced by experimental subarachnoid hemorrhage. Journal of Translational Medicine [2012, 10:80].

Eveland $\mathrm{AL}^{1}$, Goldshmidt A, Pautler $\mathrm{M}$, Morohashi K, Liseron-Monfils C, Lewis MW, Kumari S, Hiraga S, Yang F, Unger-Wallace E, Olson A, Hake S, Vollbrecht E, Grotewold E, Ware D, Jackson D (2014). Regulatory modules controlling maize inflorescence architecture. Genome Res. 24(3):43143.

Eveland, A.L., Satoh-nagasawa, n., Goldshmidt, A., Meyer, S., Beatty, M., Sakai, H., Ware, D., and Jackson, D.(2010). Digital gene expression signatures for maize development. Plant Physiol. 154, 1024-1039.

Fernandez, O., Béthencourt, L., Quero, A., Sangwan, R.S., and Clément, C.(2010). Trehalose and plant stress responses: friend or foe? Trends Plant Sci. 15, 409-417.

Fernandez, O., Vandesteene, L., Feil, R., Baillieul, F., Lunn, J.E., and Clément, C. (2012). Trehalose metabolism is activated upon chilling in grapevine and might participate in Burkholderia phytofirmansinduced chilling tolerance. Planta. 236, 355369

Garg AK et al. 2002. Trehalose 
accumulation in rice plants confers high tolerance levels to different abiotic stresses. Proc Natl Acad Sci USA 99: 15898-15903.

Gómez, LD, Baud S, Gilday A, Li Yi and Graham AI (2006). Delayed embryo development in the ARABIDOPSIS TREHALOSE-6-PHOSPHATE

SYNTHASE 1 mutant is associated with altered cell wall structure, decreased cell division and starch accumulation. The Plant Journal. 46 (1): 69-84

Gutierrez L., Van Wuytswinkel O., Castelain M., Bellini C. (2007). Combined networks regulating seed maturation.Trends Plant Sci. 12: 294-300.

Hagen, S.J., Hofrichter, J., and Eaton W.A. (1995). Protein reaction kinetic in a room-temperature glass. Science. 269 (5226):959-962.

Higashiyama, Takanobu (2002). "Novel functions and applications of trehalose". Pure Appl. Chem. 74 (7): 1263-1269.

Jang IC, Seo JS, Choi WB, Song SI, KIM $\mathrm{CH}$, KIM YS, Seo HS, CHOI YD, Nahm BH, KIM JK. 2003. Escheichia coli genes for trehalose-6-phosphate synthase and trehalose-6-phosphate phosphatase in transgenic rice plants increase trehalose accumulation and abiotic stress tolerance without stunting growth. Plant Physiol. 2003. Feb: 131 (2): 516-24.

Jovanović N, Bouchard A, Hofland GW, Witkamp GJ, Crommelin DJ, Jiskoot W. Eur J Pharm (2006).

Distinct effects of sucrose and trehalose on protein stability during supercritical fluid drying and freezedrying.[Eur J Pharm Sci. 2006Sci. 2006 Mar; 27(4):336-45. Epub 2005 Dec 9.

Karim S, Aronso H, Ericson H, Phironen
M, Leyman B, Wellin B, Mantyla B, Palva ET, van Didijck P, Holmstorm KO (2007). Improve rought tolerance without undesired side eefect transgenic plant producing trehalose. Plant Mol Biol. 64: 371-386

Klinghammer, M., and Tenhaken, R.(2007). Genome-wide analysis of the UDP-glucose dehydrogenase gene family in Arabidopsis, a key enzyme for matrix polysaccharides in cell walls. J. Exp. Bot. 58, 3609-3621.

Kolbe, A., Tiessen, A., Schluepmann, H., Paul, M.J., ulrich, S., and Geigenberger, P.(2005). Trehalose 6phosphate regulates starch synthesis via posttranslational redox activation of ADPglucose pyrophosphorylase. Proc. Natl Acad. Sci. U S A. 102, 11118-11123.

Laurie, S., McKibbin, R.S., and Halford, n.G. (2003). Antisense SNF1-related (SnRK1) protein kinase gene represses transient activity of an $\alpha$ amylase $(\alpha$-Amy2) gene promoter in cultured wheat embryos. J. Exp. Bot. 54, 739-747.

Lee, Y.A., Kim,Y.K., Kim, B.J., Kim, B.K, Kim, K.J., Auh, J.H., Schmidt J.A., Ryu B.Y (2013). Cryopreservation in Trehalose Preserves Functional Capacity of Murine Spermatogonial Stem Cells. Plos one, 8 (1):1-9.

Lefort R, Bordat P, Cesaro A, Descamp M (2007). Exploring the conformational Energy landschape of glassy disaccharide by cross polarization magic angel spinning 13C nuclear magnetic resonance and numerical simulation II enhanced molecular flexibility in amorphous trehalose. J Chem Phys 126: 014511.

Lenne, T, Bryan G, Koster KL (2007). How much solute to inhibite the fluid to gel membrane phase transition at low

hydration?. 
Biochem.Biophysic.Acta. 1768:10191022.

Lu CA, Lin CC, Lee KW, Chen JL, Huang LF, Ho SL, Liu HJ, Hsing YI, Yu SM (2007) The SnRK1A protein kinase plays a key role in sugar signaling during germination and seedling growth of rice. Plant Cell 192484 2499

Lunn, J.E., Feil, R., Hendriks, J.H.M., Gibon, Y., Morcuende, R., Osuna, D., Scheible, W.-R., Carillo, P., Hajirezaei, M.-R., and Stitt, M. (2006). Sugar-induced increases in trehalose 6-phosphate are correlated with redox activation of ADPglucose pyrophosphorylase and higher rates of starch synthesis in Arabidopsis thaliana. Biochem. J. 397, 139-148.

Magazù, S., Migliardo, F., Benedetto, A., La Torre, R., and Hennet, L. (2012). Bio-protective effects of homologous disaccharides on biological macromolecules. Eur. Biophys. J. 41, 361-367.

Martínez-Barajas, E., Delatte, T., Schluepmann, H., de Jong, G.J., Somsen, G.W., nunes, C., Primavesi, L.F., Coello, P., Mitchell, R.A.C., and Paul, M.J.(2011). Wheat grain development is characterized by remarkable trehalose 6-phosphate accumulation pregrain filling: tissue distribution and relationship to SNF1related protein kinase1 activity. Plant Physiol. 156, 373-381.

Michalska J, Zauber H, Buchanan BB, Cejudo FG, Geigenberger B (2009). NTRClink build in thiredoxin to light and sucrose in tegulating starch synthesis in chloroplast and amyloplast. Proc. Natrl Acad Sci USA 106:9908-13

Miranda, J. A., Avonce, N., Suarez, R., Thevelein, J. M., Van Dijck, P., and Iturriaga, G. (2007). A bifunctional
TPS-TPP enzyme from yeast confers tolerance to multiple and extreme abiotic stress conditions. Planta 226, 1411-1421.

Muchembled J, Loune's-Hadj Sahraoui A, GrandmouginFerjani A, Sancholle M.2006. Changes in lipid composition of Blumeria graminisf. sp. tritici conidia produced on wheat leaves treated with heptanoyl salicylic acid. Phytochemistry67: 1104-1109

O'Hara, L. E., Paul, M. J., and Wingler, A. (2013). How do sugars regulate plant growth and development? New insight into the role of trehalose-6phosphate. Mol. Plant 6, 261-274.

Patist A and Zoerb H (2005). Preservaton Mechanism of Trehalose in Food and Biosystem (2005). Science Direct (Colloid and surface B: Biointerfaces) 40: 107-113.

Pereira SC, Lins RD, Chndrasekhar I, Freitas LCG and Hynenberger PH (2004). Interaction of the Disaccharide Trehalose with a Phospholipid Bilayers: A molecular Dynamic Study. Biophys J. 86: 2273-2285.

Ponnu, J., Wahl, V., and Schmid, M.(2011). Trehalose-6-phosphate: connecting plant metabolism and development. Frontiers Plant Sci. 2, 70 .

Reignault, P., Cogan, A., Muchembled, J., Sahraoui, A.L.H., Durand, R., and Sancholle, M. (2001). Trehalose induces resistance to powdery mildew in wheat. New Phytol. 149, 519-529.

Satoh-Nagasawa N, Nagasawa N, Malcomber S, Sakai H, and Jack-son, D (2006). Atrehalosemeta-bolic enzyme controls inflorescence architecture in maize. Nature 441: 227-230.

Schluepmann H, Berke B and Gabino F. Sanchez-Perez (2012) Metabolism control over growth: a case for 
trehalose-6-phosphate in plants. J. Exp. Bot. (2012) 63 (9): 3379-3390. Cell. 9, 5-19.

Schluepmann, H., Pellny, T., van Dijken, A., Smeekens, S., and Paul, M.(2003). Trehalose 6-phosphate is indispensable for carbohydrate utilization and growth in Arabidopsis thaliana. Proc. Natl Acad. Sci. U S A. 100, 6849-6854.

Schluepmann, H., van Dijken, A., Aghdasi, M., Wobbes, B., Paul, M., and Smeekens, S.(2004). Trehalose mediated growth inhibition of Arabidopsisseedlings is due to trehalose-6-phosphate accumulation. Plant Physiol. 135, 879-890.

Shinohara ML, Correa A, Pedersen DB, Dunlap JC and Loros JJ (2002). Neurospora Clock Cpntrolled Gene 9 ccg-9 Encodes Trehalose Synthase: Circadian Regulation of Stress Responses and Development. Eukayotic Cell. 33-43.

Silje HHW, Paalman JWG, ter Schure EG, et al. 1999. Function of trehalose and glycogen in cell cycle progression and cell viability in Saccharomyces cerevisiae. J Bacteriol 181: 396-400.

Singh V, Louis J, Ayre BG, Reese JC, Pegadaraju V, Shah J. (2011). TREHALOSE PHOSPHATE SYNTHASE11-dependent trehalose metabolism promotes Arabidopsis thaliana defense against the phloemfeeding insect Myzus persicae. Plant J. 67(1):94-104.

Smeekens S., Ma J., Rolland F. (2010). Sugar signals and molecular networks controlling plant growth. Curr. Opin. Plant Biol. 13 177-191

Smeekens S., Ma J., Rolland F. (2010). Sugar signals and molecular networks controlling plant growth. Curr. Opin. Plant Biol. 13 177-191

Tayeh, C., Randoux,B., Vincent, $\quad$ D., Zentella, R., Mascorro-Gallardo, J.O., Van
Bourdon, N, and Reignault P. (2014). Exogenous Trehalose Induces defenses in Wheat Before and During a Biotic Stress Caused by Powdery Mildew. Genetics and Resistance. 104(3):293305

Testerink C and Munnik T (2011). Molecular, Cellular and Physiological responses to phosphatidic acid in plants. J. Exp. Bot. 62: 2349-2361

Tsai, A.Y.L. and Gozarrini $\quad$ S. (2014). Trehalose-6-phosphate and SnRK1 kinases in plant development and signaling: the emerging picture. doi: 10.3389/fpls.2014.00119

van Dijken, A.J.H., Schluepmann, H., and Smeekens, S.C.M.(2004). Arabidopsis trehalose-6-phosphate synthase 1 is essential for normal vegetative growth and transition to flowering. Plant Physiol. 135, 969-977.

Wahl V., Ponnu J., Schlereth A., Arrivault S., Langenecker T., Franke A., et al. (2013). Regulation of flowering by trehalose-6-phosphate signaling in Arabidopsis thaliana.

Science. 339:704-707

Wang, L. and Ruan Y.L. (2013). Regulation of cell division and expansion by sugar and auxin signaling. Front. Plant Sci., 30 May 2013.

Wingler, A., Delatte, T.L., O’Hara, L.E., Primavesi, L.F., Jhurreea, D., Paul, M.J., and Schluepmann, H. (2012). Trehalose 6-phosphate is required for the onset of leaf senescence associated with high carbon availability. Plant Physiol. 158, 12411251.

Wu, L., and Birch, R. G. (2010). Physiological basis for enhanced sucrose accumulation in an engineered sugarcane cell line.Funct. Plant Biol.37:1161 -1174. 
Dijck, P., Folch-Mallol, J., Bonini, B., VanVaeck, C., Gaxiola, R., Covarrubias, A.A., NietoSotelo, J., Thevelein, J.M., and Iturriaga, G. (1999) ASelaginellalepidophylla trehalose-6-phosphate synthase complements growth andstresstolerance defects in a yeast tps1
mutant.Plant Physiol., 119,1473-1482 Zhang R, Pan YT, Lam M, Brayer GD, 007AElbein AD, Whithers SC (2011). Mechanistic analysis of trehalose synthase from Mycobacterium smegmatis. J. Biol. Chem 266:3560135609 . 